\title{
Speaking Out Into a New Future
}

\section{Ted Lankester ${ }^{a}$}

${ }^{a}$ MA, MB, BChir, MRCGP, RCPSGlasg is founder of Community Health Global Network and Director of Health Services, Interhealth, UK.

For generations, Christian health professionals have pioneered and provided health care for the neediest people on our planet. ${ }^{1}$ For the most part, their work has been largely unrecognized. Many have been so busy caring for people and programmes that they have never documented their activities. After all, when you are operating on the war wounded through the night, driving back late from your remote clinic, or trying to run a hospital with three senior staff members off sick, there is not much time to write up perfect reports or manicure statistics. As for writing research papers or contributing to health policy, well, that will have to wait -probably indefinitely.

As a result, some of the greatest stories of practical service and health impact have never been told. Many have not even been recorded, meaning that governments may be almost entirely unaware of their existence, let alone their contributions. In addition, the secular mind sets of donors, policy makers, and the media have often done little to correct these misconceptions. As a result, faith-based organisations (FBOs) are frequently the hidden providers of health care, and more often than not, the unsung heroes. But, the good news is that, over the past few years, perceptions and realities are starting to change.

Bodies, such as the World Health Organization, have documented the role of FBOs, and major donors have acknowledged their special contribution. ${ }^{2,3,4,5}$ Policy makers, albeit grudgingly, are starting to recognize a truth, only too obvious to most field workers, that a worshipping community, be it temple, mosque, or church, is present in virtually every place on earth where people gather, work, or live together. Moreover, members of such groups are the obvious proponents and providers of service to their communities, if only they can be identified, trained, and resourced.

Christians and members of other faiths are beginning to find a voice. That voice is a good start, but to have any impact a voice needs to be amplified. The Christian Journal of Global Health is designed to be one such amplifier. Through the Journal, stories, anecdotes, operational research, and the impact of faith-based programmes have a vehicle to make their previously little known contributions clearly available to a wider audience.

When Jesus told us to pray regularly "Your Kingdom Come, your will be done on earth as it is in Heaven," (Matthew 6:10) ${ }^{6} \mathrm{He}$ was calling us to a here-and-now mandate to serve the world with compassionate and creative love to show, practically, how God's "saving health" (Psalm 67:2) ${ }^{7}$ can be shown in the slum alleyways, refugee camps, and in distant hilltop communities. Incarnation usually comes before Redemption. The living embodiment of a God who is here with us in our pains, sorrows, and celebrations is the forerunner of what that same God enacts with and through us in redeeming the world for a new future.

Christian and other faith-based health professionals are in a privileged position to help bring this about with a measured and unwavering voice to share widely just how this is happening. By the end of 2015, we will be coming to the end of the Millennium Develop- 
ment Goals (MDG). ${ }^{8}$ We have much to celebrate.

Soon, we will be transitioning to Universal Health Coverage ${ }^{9}$ and the Sustainable Development Goals. ${ }^{10}$ As people of faith, we should embrace these new initiatives with eagerness and not carp and criticize that they won't always live up to our perfectionist hopes. They, and other emerging goals, give us a renewed mandate to become deeply re-involved through service, policy formation, evidence based health programmes, and creative models of service.

We have an open door and a wide road stretching before us. It's a moment in history to grasp the promises of God and claim the energy "he mightily inspires within us" to make an even greater contribution to the welfare of our world. It's an opportunity to promote healthcare not only for its primary purpose of bringing renewed health and wellbeing to communities but also by pursuing community-agreed health priorities to act as an agent for reconciliation.

We must also work with a new confidence to share expertise and motivation with governments, donors, and policy makers. This will often mean forgetting our small differences for the sake of a more effective service for humankind. Without losing our distinctives, we can unashamedly contribute and influence the practice of global health in a new generation.

The Christian Journal of Global Health can be a vehicle in which we encourage, document, speak, and promote the unique contributions of the church and other faith communities. With God as our Creator and our legitimate claims to sometimes "hear his voice and understand his ways," we should be surfing the crest of the wave and not waiting till that same wave has broken farther up the beach. We should be in the forefront of creative policy and not spend energy in playing catch-up. And yet, whilst recognizing the value of our faith-based distinctives, we must also affirm that humanitarianism has its roots in Christian values $^{11}$, and, as a result, we have a valid and essential overlap of policy and practice with those who may not share our faith, but who do inherit a God-given instinct to make the world a fairer, safer, and healthier place.

We must share our insights and pioneer collaborations that will lead to a greater good. We need to clearly believe and demonstrate that the Kingdom of God carries a far greater model for service than simply encouraging Christians to serve and protect their own. This is not the time to hold back and to retreat into our religious corners. Neither is it a time to make triumphalist claims about aspirations we have not yet reached, but it is an opportunity for us to demonstrate, more intentionally, a range of models which combine compassion, evidencebased healthcare, and useful collaborations as we move into the post-MDG era.

I hope and pray that, within a few years, we will look back at the contribution this Journal has made to these new goals, more complex needs, and larger populations, and thank God we are making a valid -- and carefully captured -record of what is being done in God's name.

\section{References}

1. Browne SG, Davey F, Thomson WAR, editors. Heralds of health: The saga of Christian medical initiatives. London: Christian Medical Fellowship; 1985.

2. Towards primary health care: Renewing partnerships with faith based communities and services. Geneva: Report of World Health Organization consultation with faith based organisations; 17th-18th Dec 2007.

3. Schmid B, Thomas E, Oliver J, Cochrane JR. The contribution of religious entities to health in SubSaharan Africa, study commissioned by Bill and Melinda Gates Foundation. Cape Town: African Religious Health Assets Programme; 2008.

4. A Firm Foundation: The PEPFAR Consultation on the role of Faith Based Organizations in Sustaining Community and Country Leadership in the Response to HIV/AIDS. Atlanta, Georgia: Report of the U.S. President's Emergency Plan for AIDS Relief and the Interfaith Health Program; 2012. (Project Number ASPH S3552-24/29). 
5. Faith Partnership Principles - working effectively with faith groups to fight global poverty. Report of the Department for International Development;

United Kingdom; 2012. Available from https://www.gov.uk/government/uploads/system/ uploads/attachment_data/file/67352/faithpartnership-principles.pdf

6. The English Standard Version Bible. Oxford: Oxford University Press; 2009.

7. The Holy Bible, containing the Old and New Testaments, King James Version: New York: American Bible Society; 1999.

8. Millennium Development Goals [Internet]. Geneva: The World Health Organization; 2000.

Available from http://www.un.org/millenniumgoals/
9. United Nations Resolution on Universal Health Coverage [Internet]. Geneva: The World Health Organization; [updated 2012 Dec 12; cited 2014 Mar 17] Available from http://www.who.int/universal health_coverage/en/

10. Sustainable Development Goals [Internet]. Geneva: The World Health Organization; [updated 2013 Dec; cited 2014 Mar 17] Available from http://sustainabledevelopment.un.org/index.php?men $\underline{\mathrm{u}=1300}$

11. The Universal Declaration of Human Rights [Internet]. New York, NY: The United Nations; [10 December 1948; cited March 17, 2014] Available from http://www.un.org/en/documents/udhr/

Competing Interests: None declared. Dr. Lankester is a member of the International Advisory Board of CJGH

Correspondence: Dr. Ted Lankester, 63 - 67 Newington Causeway, London, SE1 6BD. ted.lankester@chgn.org

Cite this article as: Lankester, T. Speaking out into a new future. Christian Journal for Global Health (2014), $1(1): 3-5$

(C) Lankester. This is an open-access article distributed under the terms of the Creative Commons Attribution License, which permits unrestricted use, distribution, and reproduction in any medium, provided the original author and source are properly cited. To view a copy of the license, visit http://creativecommons.org/licenses/by/4.0/

www.cjgh.org 